\title{
President Brand's Gambit: Inviting Scholars Inside the Tent
}

\author{
Scott Kretchmar
}

Pennsylvania State University

One of Myles Brand's priorities during his Presidency of the National Collegiate Athletic Association (NCAA) was to increase research activity on intercollegiate athletics. This objective was as much personal as it was strategic. Brand was an academic himself. He loved scholarly interchange, and he loved sport. A philosopher by training, he read research in sport ethics, wrote articles about the educational value of sport for refereed journals (Brand, 2006), and taught university-level courses on sport philosophy. ${ }^{1}$ He noticed that many fellow academics were as interested in sport as he was, but relatively few of them included it in their research portfolios. He wondered why this was the case and what, if anything, he could do to correct it. As the incoming President of the NCAA, he realized he would have both a bully pulpit and institutional resources to press forward with these personal interests.

The strategic aspect of this agenda is more difficult to discern. Most of the scholarship that existed at that time on Division I college athletics ranged in tone from politely skeptical to openly hostile. Brand was not naïve to this reality. While President at Indiana University Bloomington he not only had to deal with the mercurial, chair-throwing, athlete-choking Bobby Knight, but he also had to endure the attention-grabbing, sport-vilifying Murray Sperber (2000), a faculty member in English and American Studies at Indiana and author of Beer and Circus: How Big-Time College Sport is Crippling Undergraduate Education. While Sperber was a local thorn in Brand's flesh, he was just one among a number or other scholars who had little good to say about intercollegiate athletics of the late $20^{\text {th }}$ century. For instance, John Thelin (1994), D. Stanley Eitzen (1999), Andrew Zimbalist, (1999), James Duderstadt (2000), as well as James Shulman and William Bowen (2000) among others, had written pointed critiques of what they saw as an unholy marriage between higher education and big-time intercollegiate sport. Why, then, would President Brand think it advantageous for the NCAA to stimulate what promised to be more of the same? As we will see, Brand had his reasons. 


\section{An Early Aborted Venture}

In 2005, two years after assuming the reigns of the NCAA Presidency, Brand charged his national office's events staff to make plans to produce a scholarly conference. It would be held in conjunction with the NCAA's centennial celebration and annual convention in January, 2007, Orlando, Florida. A call for papers was issued.

It received a tepid response. Scholars, in general, were skeptical of the NCAA's intentions as reported in Inside Higher Education:

Several scholars who submitted papers ... said that they had wrestled with issues about whether the NCAA could put on a legitimate scholarly conference about college sports. But they said they had ultimately decided that the association deserved the benefit of the doubt and that 'a scholarly exchange right in the heart of the NCAA decision making process' was worth encouraging, as one put it (Lederman, 2006, p. 2).

Many scholars, however, chose not to give the NCAA the "benefit of the doubt." Thus, in the fall of 2006, just months before this unprecedented conference was to take place, it was cancelled. This came as no surprise to long-time critics of the NCAA. They "didn't like the stuff they were receiving. [It was] too critical of the NCAA," one scholar suggested (quoted in Lederman, 2006, p. 1).

When it was later announced that the NCAA would sponsor a 2008 conference that featured "four invited scholars of international repute," even more stinging criticisms were generated:

The NCAA, in my humble professional opinion, is not satisfied with sponsoring athletic championships, and monopolizing college sports. It seems determined to also purchase any and all critical academic discussion surrounding intercollegiate athletics. I am struck by the similarity of this situation to the NCAA's tactics in its recent purchase of the NIT.

To purchase as much of the dialogue as possible, the NCAA will sponsor a BCS-like colloquium with only four scholars speaking as representatives for all. I have no doubt the NCAA will publicize this controlled scrimmage as an example of its commitment to its educational mission (Southall, 2007, pp. 4-5).

Brand pushed back against these explanations and called them "conspiracy theories." The papers received, he explained:

... were not of the quality one would expect of a scholarly conference, or at least there were not enough of them to put on a scholarly conference .

. . [Consequently] rather than put on a mediocre conference and get off

to a bad start, [the Association would start planning again] from scratch" (Lederman, 2006, p. 1).

Brand appears to have made two miscalculations in addition to a strategic error. First, he mistakenly believed that an unprecedented conference of this sort would be popular with academics. He expected a number of new and well-established scholars to submit papers and attend the meeting. Second, he erred in believing that the more acerbic critics of intercollegiate sport would either choose not to attend or participate 
in less polemical ways than had been their wont. Brand was wrong on both counts. Previously unengaged academics chose by and large to stay away, and a number of intemperate critics did not.

The strategic error was just as serious as the two miscalculations. Brand relied on NCAA national office staff to organize and publicize the event. He admitted he put the conference in the hands of "really nice people on the NCAA staff." [But they were] "non-academicians [who] really didn't understand [how to stage a scholarly conference]" (Lederman, 2006, p. 2).

This led to an unexpected phone call I received on Thursday afternoon, August 3, 2006. I picked up the receiver. The person on the other end of the line introduced himself, "This is Myles Brand."

\section{Initial Conversations and Negotiations}

I knew who Myles Brand was. Myles and I had met briefly on one occasion prior to this call. I was the NCAA Faculty Representative for Penn State and served on the NCAA Division I Management Council. At a recent meeting of the Council, Myles and I had made small talk during one of the breaks in the Council's business. Unbeknownst to me, however, he had used some of my articles in his sport philosophy class and was aware I was one of the elders in the International Association for the Philosophy of Sport. Our phone conversation was brief. He came to the point quickly.

He mentioned the NCAA's previously aborted attempt to organize and host a conference. I had submitted an abstract myself and told him I was aware of the cancellation. He said he believed that more research directed to college athletics was needed, and he was determined to foster it through the NCAA.

He needed someone to lead this effort. He wanted help in forming a Board composed of individuals he described as "the very top scholars" in the various disciplines of sport research. He wanted this Board to meet in person regularly and to organize an annual symposium. He said the NCAA would underwrite this project and give Board members the freedom to conduct high-quality research symposia in the ways they judged appropriate. I would work directly with him, three of his top direct reports - Wally Renfro (Vice President and Chief Policy Advisor), Dennis Cryder (Senior Vice President for Branding and Communications), and Todd Petr (Managing Director of Research) — as well as others at the NCAA national office in the process of recruiting Board members and conducting these meetings.

This call had come without forewarning. I had mixed emotions. I told Brand I would need time to consider his proposal.

My initial inclination was to decline the offer, and I felt I had a number of good reasons for doing so. Some were personal. I was fully engaged in my own research program. I had a number of doctoral students who needed my attention, and I realized this would be a time-consuming and potentially stressful addition to my schedule.

Moreover, I barely knew Myles Brand, and he did not know me. Would we work well together? Could we trust one another in dealing with sensitive issues? Would 
our philosophies be compatible? Moreover, much like some of my colleagues who expressed reservations about the motives of the NCAA in hosting an academic conference, I was wary of institutional norms and purposes of the NCAA. Brand was the head of a multi-million dollar enterprise, not an academic institution. I wondered about ulterior motives.

During our brief conversation, Brand told me he wanted to invite more scholars inside the NCAA tent. He said it would be a healthy relationship, and he lamented the fact that so few top-level researchers addressed issues in collegiate sport. Brand sounded very sincere, but I suspected additional agendas might be in play. For instance, as a Faculty Representative, I knew the NCAA survived on the tenets of amateurism, on the claim that athletes were students not employees, and on the financial benefits accruing from 501 (c)(3) tax exempt status. Sponsorship of a scholarly colloquium would help fortify the NCAA's image as an educationally-tethered organization, an institution that deserved such tax benefits. The Colloquium would serve as an insurance policy of sorts for the NCAA.

Other worries were related to the status of the colloquium itself. Would an NCAA-funded conference whose founding impetus came from the NCAA President himself enjoy any credibility? How could an academic board claim independence when its very existence depended on NCAA largess? Would my own and other colleagues' professional reputations be sullied by mere association with such a project? How would Brand and other NCAA executives react if we wanted to invite an NCAA critic to serve on the Board, or if the Board wanted to invite such a scholar to be a featured symposium speaker? I could picture myself caught in an untenable position between the interests of academic board members on the one hand, and the wishes of Brand and the NCAA, on the other. Would we have sufficient freedom to operate as we wished? If so, would we be able to convince others that we were not working under the shadow of potential NCAA censorship?

Arguments, however, also existed on the side of accepting Brand's offer. His proposal seemed timely. Athletic reform was a popular topic in the two decades extending from 1990 to 2010. The first Knight Commission report (Keeping Faith with the Student-Athlete: A New Model for Intercollegiate Athletics) was issued in 1991. A second report (A Call to Action: Reconnecting College Sports and Higher Education) was published 10 years later. These two documents called for stronger institutional leadership from presidents, trustees, and faculty, as well as academic and fiscal reform.

In addition, two national faculty organizations devoted to intercollegiate athletic reform were founded during this 20-year period. The more aggressive and critical of the two, The Drake Group, was established in 1999 with a mission of "defending academic integrity in higher education from the corrosive aspects of commercialized college sports" (p. 1). Drake Group members and others founded the College Sport Research Institute in 2007. It continues to sponsor annual meetings, and publishes its own peer-reviewed Journal titled, Journal of Issues in Intercollegiate Sport.

Another athletic reform organization, The Coalition on Intercollegiate Athletics, was founded in 2003 and consists of faculty governance leaders at Division I insti- 
tutions. Its stated purpose is to "promote academic excellence, integrity and student well-being in intercollegiate athletics." It published its reform agenda in 2007 in a document titled, Framing the Future: Reforming Intercollegiate Athletics.

It was also during these two decades that the American Association of University Professors (AAUP) weighed in on athletic reform. In 2002 the Committee on Teaching, Research, and Publication produced a document titled, The Faculty Role in the Reform of Intercollegiate Athletics.

The time was ripe for reform in intercollegiate athletics, and Brand understood that. At the start of his tenure in 2003, he formed a commission of 50 Presidents and Chancellors to examine reforms related to fiscal sustainability and academic integrity. Brand gave a speech to the National Press Club in which he emphasized these fiscal and academic themes along with social justice issues related to race and gender (Brand, 2003). It seemed clear that Brand was going to provide reform-targeted leadership for the NCAA.

I contacted his office and indicated I would like to talk further about his proposal for the colloquium and my involvement in it.

\section{Initial Meeting and Follow-up Conversations}

Later in August, we scheduled a one-on-one meeting in his Indianapolis office. We both came prepared with important agenda items that required discussion.

Brand raised an issue that did not surprise me. How would we monitor participation? How could we prevent those who merely wanted a stage on which to air extreme and incendiary ideas from harming the reputation of the colloquium? This was a question about the intersection of good scholarship and politics, free speech and potentially controversial research. Colloquium sessions, he reminded me, would be open to the press and media coverage. Brand was concerned about negative publicity for the NCAA, something he had already experienced with the postponement of the first colloquium. However, as an academic himself, he was also well aware of the value and importance of open, unfettered inquiry.

I recounted our procedures at philosophy of sport conferences related to the careful review of abstracts and our commitment to accepting a wide range of well-argued papers, even those with unpopular views as long that they violated no ethical standards and were supported with solid reasoning.

Brand expected this answer but had a follow-up question. "Did you ever have anyone misrepresent his intentions and falsify an abstract for the sole purpose of getting on the program to vent personal or unsupported political views." I told him it had happened only once to my knowledge. I was chairing the session in which it took place. It involved a slanderous attack on a person, a scholar who happened to be present in the room.

I told Brand we quickly dismissed the person from the podium. We apologized to the party that was attacked and told him the perpetrator had intentionally misrepresented the nature of his talk. No press members were in attendance. I concluded that the incident was regrettable but caused little or no harm to the reputation of our 
scholarly society. I well understood that such would not be the case if a like incident occurred during an NCAA Colloquium. I read Brand as concluding that he and the NCAA would incur a degree of risk in this regard. It was unavoidable.

Brand raised a second issue of concern - the composition of the Colloquium Board. He had some nominations in mind and wanted my reaction. Two of them were academics with research interests in sport. I knew both of them personally. Each one was a highly regarded scholar with excellent national and international reputations. He also mentioned a third individual - a professor from a prestigious university whose research interests fell outside intercollegiate athletics but nevertheless sat on a number of NCAA committees and had a long history with the NCAA. In my role as Faculty Athletic Representative, I had worked with this person and knew he enjoyed a fine reputation.

These were three individuals with whom Brand was comfortable. He would have a cadre of individuals on the Board who were moderates, who were not confrontational or polemical by nature, who had not been openly critical of the NCAA. Yet, they were people of integrity and intelligence. I told Brand I would have no problem inviting them to serve on the Board.

Brand's nominations, however, reinforced concerns I had about the credibility of the Board - namely, how it would be perceived by academics who prized free inquiry, objectivity, and unfettered scholarly dialogue? Credibility, I thought, would be enhanced by adding members who met two criteria. They had to be at the top of their discipline - whether it be sport sociology, physiology, journalism, business, law, or philosophy. Second, they had to have a reputation for scholarly objectivity, for calling out questionable or indefensible aspects of NCAA sport when and where it was warranted.

I mentioned names of a few individuals to Brand, several of whom were Fellows in the National Academy of Kinesiology. I talked about a couple of individuals from the humanities and social sciences who had written pointed but, in my judgment, balanced books that included critiques of certain aspects of intercollegiate sport. If the Board was to enjoy any credibility, some of these individuals would need to be seated as members. Brand quickly agreed and said something that helped answer that lingering question I and others had about strategic benefits of the colloquium that might accrue to the NCAA.

Brand said he was not afraid of good, critical scholarship. He knew that certain matters in NCAA sport needed fixing and that positive change would be difficult. However, he believed that good scholarship would also tell the larger story about the many benefits of being an intercollegiate athlete. Solid research, in other words, would uncover good stories to go along with the bad. Moreover, well-grounded critical analyses would help identify and direct reform efforts. Movement forward, he noted, would not be possible without good information.

Brand said he believed in the educational value of intercollegiate sport. It was a unique setting for learning. Unbiased research, he believed, would reveal what he saw as a frequently untold story about all the good that athletics added to a college 
education. Brand wanted critics and critical thinking on the colloquium Board. We agreed on several additional names for invitation to Board membership.

I had additional concerns about chances for success in recruiting renowned, busy scholars, some of whom would be skeptical about the merits of the project. I needed to tell them that an initial assignment for the Board would be one of writing a constitution that clearly spelled out the Board's composition, duties, operations, and rights. Something in the constitution would need to assure its independence. Brand and I discussed the matter and agreed on the terms "intellectual autonomy." When I contacted potential Board members, I would be able to say we will have a clause in our constitution that promises intellectual autonomy. I could tell them such a clause will be endorsed by all parties, including the President of the NCAA.

Brand was not at all reluctant to endorse the tenet of intellectual autonomy. When I was about to contact one of the top recruits for the Board, Brand sent me a note in which he reminded me not to forget to mention intellectual autonomy during my phone call (personal correspondence received September . . 2006.) Months later when a press release was being developed to announce the Scholarly Colloquium, Brand wrote to Dennis Cryder:

All this is good, though I have one suggestion. The Press Release does not explicitly reference that the Board will exercise intellectual autonomy. The talking points cover this, especially the third and fifth ones. I suggest that a sentence be added to the Press Release that makes this point [about intellectual autonomy] probably in the third paragraph (personal correspondence to D. Cryder, January 22, 2007).

\section{The Board, First Colloquium, and the Founding of the Journal}

Recruitment of scholars was the first order of business. It would be diverse in terms of gender and ethnicity. But other considerations were also important. It needed to include members from all three NCAA Divisions. Even though most top sport scholars were in Research I institutions that sponsored Division I sport programs, athletic issues deserving attention existed at all three governance levels.

The original Advisory Board included 16 members, all of them top scholars in their respective areas:four from sport philosophy, two from sport management, two from education, and one each from psychology, educational psychology, business, sport law, sport journalism, physiology, sport sociology, and child development. We identified ourselves in our Constitution as "The Forum for the Scholarly Study of Intercollegiate Sport in Higher Education."

The inaugural colloquium was held January 10-11, 2008 in Nashville in conjunction with the NCAA Convention. The theme was foundational to our purpose and was stated in the form of a rhetorical question: "College Sports: A Legitimate Focus for Scholarly Inquiry?" We selected four speakers who were likely to be provocative and insightful. 
The meeting was held in a cavernous auditorium, one that accentuated the very modest attendance at that first session. However, Brand was sitting with others in the first row. We would be addressing the question on which he was passionate - the need for more and better research on intercollegiate sport.

The lead speaker, sport sociologist Jay Coakley, titled his talk: "Ignore, Idealize or Condemn: 'Scholarly' Approaches to Intercollegiate Sports." He detailed the many challenges faced by scholars who attempted to do research on big-time college sport. He mentioned that Division I programs typically kept researchers at arm's length and prevented them from seeing inside the institutional walls, particularly those that protected data on finances. He warned that attempts to conduct meaningful research on intercollegiate sport would likely be frustrated by these kinds of roadblocks.

Brand was listening and seemed to take Coakley's arguments to heart. Shortly after the meetings closed, Brand arranged for the dissemination of large amounts of athletic data through a University of Michigan resource center. ${ }^{2} \mathrm{He}$ also directed his research staff to post data on the NCAA website related to his several academic reform efforts. Researchers, moving forward, would have more and better information on which to conduct their studies.

This was precisely the kind of interaction we hoped the Colloquium would generate. Other papers at that first meeting by Bob Simon, a sport ethicist from Hamilton College, a Division III school; by John Thelin, an educational researcher from the University of Kentucky who had authored books on the uneasy interface of athletics and higher education; and Mary Jo Kane, a scholar from Minnesota who had completed research on educational support for athletes who were academically "fragile." All four papers provided fodder for future colloquium meetings by underlining the complexities of intercollegiate sport and drawing attention to its normative ambiguities.

Reviews of that first meeting were generally positive. Doubts about the credibility of our efforts were eased, if only modestly. The progress was only modest because the Colloquium Board had selected the four speakers. It left itself open to charges of conducting a "controlled scrimmage." However, according to reports in Inside Higher Ed, the Board had selected well:

Steve Walk, a professor of sport sociology at California State University at Fullerton and a former president of the North American Society for the Sociology of Sport, said it was satisfying to see NCAA staff listening to commentary from some of the top sports scholars who previously haven't had a stage.

'How can I be against that?' said Walk, who was among the academics who last year questioned whether the NCAA was the appropriate group to host a no-holds-barred college sports issues meeting. 'People aren't pulling punches. There is a bit of selecting going on with the speakers, but they've chosen well' (Powers, 2008, p. 1).

Jay Coakley, the lead speaker, noted that he saw an "attempt by the board to find a diversity of 
Speakers ... I owe the NCAA nothing, and I've been critical of it in the past," he said. "So the fact that I was invited is encouraging. They could have picked a safer choice" (Powers, 2008, p. 2).

When asked by reporters about the possibility of open, scholarly exchange in an event sponsored by the NCAA, I responded that "the mics are open to the audience; people are using them." I also noted the inherent challenges generated by the colloquium:

Kretchmar acknowledged that the questions about the NCAA's involvement are worth asking. He said he pushed for tenured faculty and longtime sports scholars to speak at the conference and serve on the board, [individuals] who would not be easily influenced by outsiders. Is it possible that research goes in a direction that's unacceptable because it's so disagreeable? Sure. Some of the research findings might make the NCAA uncomfortable. I figured these tensions would be there (Powers, 2008, p. 2).

Subsequent colloquia followed a similar format, although an important modification was made for the second and subsequent colloquia. Open (refereed) papers would be solicited beginning in 2009. In planning these meetings, conversations by the Board revolved around two overriding questions. First, which intercollegiate athletic issues were most pressing and deserved attention? Second, which scholars would be best able to address those issues? Themes and keynote speakers for the following five meetings were the following:

\#2) Theme: Paying the Price: Is Excellence in Sport Compatible with Good Health? (2009)

Keynote Speakers: Dan Gould, Ron Zernicke, Matthew Mitten, and Mariah Burton Nelson

\#3) Theme: College Sports in Recessionary Times: Assessing Challenges and Opportunities (2010)

Keynote Speakers: Rodney Fort, Rick Hesel and Amy Perko, Richard Lapchick, and Andrew Zimbalist

\#4) Theme: Social Justice in Intercollegiate Sport: A Critical Examination of Racialized, Gendered, and Disabled Bodies (2011)

Keynote Speakers: Alan Sack, Harry Edwards, Susan Cahn, and Ted Fay

\#5) Theme: NCAA Academic Reform: Progress, Problems, and Prospects (2012)

Keynote Speakers: Michael Oriard, Todd Petr and Tom Paskus, Walt Harrison, a Panel of Presidents, Chancellors, and Athletic Directors including Sidney McPhee, Carol Cartwright, Harvey Perlman, Kevin Anderson, and Mike Alden 
Brand was not involved in Board conversations on conference themes or selection of the speakers. Interestingly, however, four of the first five meetings addressed issues that were among Brand's priorities (See Brand, 2003): increasing research on intercollegiate sport, developing an economically-sustainable model for athletics, improving social justice (particularly for women and black athletes), and finally raising standards and enhancing academic performance. The Board exercised its "intellectual autonomy" by inviting keynote speakers that included both critics and supporters. Characteristic of many top scholars, they also met two of Brand's criteria for good scholarship. They favored reasoned dialogue over polemics, and they provided evidence and sustained argumentation for their conclusions.

\section{The Journal of Intercollegiate Sport}

In our early conversations, Brand and I discussed problems with the dissemination of research. At that time, the lack of scholarship on intercollegiate sport was reflected in (and perhaps, in part, caused by) the lack of journals and other research outlets for reporting such work. We planned to pursue a publisher for a new Journal. We found one that was well-known in Kinesiology circles-Human Kinetics Press (HKP). HKP was a good fit because it had a lengthy history of publishing books and journals related to sport, health, athletics, and education. An agreement was reached with HKP prior to the first colloquium.

A primary audience for both the colloquium and the journal would be the faculty athletics representatives (FARs). NCAA bylaws require that each institution (roughly 1,100 schools across three divisions) have at least one such individual. I attended the Faculty Athletics Representatives Association (FARA) meetings prior to colloquia and advertised our meetings in FARA Voice. In addition, Brand agreed to provide all faculty representatives with a free subscription to the new journal, a decision that carried a significant price tag. However, we felt it important to engage the faculty both for purposes of informing them and stimulating them to engage in sport-related research.

As the first editor of the Journal of Intercollegiate Sport, I wrote an extended introduction that recounted the leadership provided by Brand, reviewed the work and purpose of the Colloquium and its Board, and touched on the themes of reform and controversy. I remember spending a great deal of time on both.

As a reform-oriented sport ethicist, I had been involved for years with the Coalition on Intercollegiate Athletics (COIA) and other similar organizations devoted to reform. Thus, speaking from my own convictions, I addressed that topic:

I cannot speak for all Board members, but if optimism [regarding successful reform] brings with it a degree of idealism and naivete, I accept that as a fair criticism. It is important, however, to reemphasize the point that research is not a panacea for reform. Although research may be a necessary component of effective change, it is certainly not also sufficient. It is not sufficient because social change requires commitment, energy, resolve, courage, organized intervention, social pressure, political strategies, strong leaders, and 
more - matters that far transcend the Board's purposes and abilities and factors over which we have little control. Nevertheless, efforts to replace hypotheses, suppositions, impressions, biases and even, on occasion, heated polemics with solid information and reasoned dialog are not trivial tasks. If current reform efforts are to persist, and persist to good effect, research will need to play a central role (Kretchmar, 2008, p. 5).

I also thought it best to address the issue of NCAA influence directly rather than skirt around an issue that would invariably be on readers' minds. It proved to be a difficult statement to write, but I attempted to capture the sentiments expressed by members of our Board:

On the issue of potentially controversial scholarship, we want to be very clear. The Board welcomes good scholarship that would tend either to support current practice or challenge the status quo. The central issue is not where the research falls on the political landscape but what the quality of that work is. Thus, the presence or absence of controversy is, and should be, a byproduct of this commitment to quality, not an objective. Consequently, we do not plan to publish editorials, polemical essays, or any other articles that are designed to inflame or arouse more than enlighten (Kretchmar, 2008, p. 7).

These flowery words notwithstanding, all of us on the Board knew that we would have different opinions over what counted as "good scholarship," and what a "commitment to quality" entailed. Those members of the Board who had been more critical of the NCAA would endorse broader definitions. Those Board members who saw NCAA sports in a more favorable light would be more skeptical of highly critical contributions. Not surprisingly, we were soon put to the test.

\section{A Potential Crisis Over Board Membership}

Our Constitution stipulated Board composition, terms of service, and procedures for selecting replacements. Board members would serve three-year staggered terms. In order to satisfy these requirements, we needed to elect several new members shortly after the conclusion of the second colloquium. The Nominations Committee presented a slate of candidates for election by the Board.

One of the nominees was a staunch critic of the NCAA and was known to seek out and garner press attention when attacking big-time college sports. This person was also broadly regarded to be a competent scholar. The Board already included at least three individuals who were well-known for taking adversarial positions against the NCAA and some of its policies, but none of them were as visible or extreme in voicing their anti-NCAA sentiments as was this particular nominee. I sensed there would be trouble.

Consequently, I was not surprised to hear from Brand himself. He asked about the rationale for this nomination. Because I was not a member of the Nominations Committee, I had little to tell him apart from the obvious. This individual was con- 
sidered by members of the committee to be a very good scholar, and this person's expertise lay in an area we would be addressing at a future colloquium. Brand said he thought it would be a mistake to add this individual to the Board.

Brand and I both knew that any unilateral effort by either one of us to remove this person from the slate of nominees would violate our Constitution and, in all probability, lead to some Board resignations. If the nominee were to be withdrawn from consideration, the Board would have to make that decision itself. I asked Brand to address this issue at our next Board meeting and express his concerns prior to the Board's vote.

Brand attended our meeting and made comments specific to the nominee. Board members listened, asked questions, and expressed views of their own. The conversation was frank and collegial. My sense was that Brand spoke more as a colleague and fellow scholar than President of the NCAA. At the end of his comments, he left the meeting . ... and left us to our deliberations and vote.

Board members acknowledged the points made by Brand, and there was a general feeling we did not want to jeopardize the progress we were making via the colloquium and the journal by pressing this particular issue. A compromise was suggested, and it received unanimous support. We would invite the controversial nominee to a future Colloquium as a keynote speaker but not add this person to the Board. A crisis had been averted, at least for the time being.

\section{The Demise of the Forum and Scholarly Colloquium}

The Colloquium survived for six years. It was defunded by the NCAA in January of 2013. Several reasons were given for this withdrawal of support. First, attendance at Colloquia was poor and subscriptions to the Journal were relatively weak. Moreover, support of the meetings and the Journal was costly. The money, some at the NCAA national office argued, might be better spent elsewhere. Finally, the content of the research presented at the colloquium, according to some NCAA staff executives, had turned in a negative, excessively critical direction.

Jim Isch, the Chief Operating Officer at the NCAA, in a very general statement said the colloquium "has not developed the way we hoped" (Grasgreen, 2013, p. 1). Senior Vice President, Wally Renfro, was more specific.

I was hearing virtually one voice being sung by a number of people, and it was relatively critical of the NCAA's academic reform effort . . . If you lose the capacity for this platform to be a dialogue, it isn't a colloquium anymore. Some might call it a rant" (Grasgreen, 2013, p. 2).

One important voice, of course, was missing from this decision to defund the colloquium - that of Myles Brand. Brand's untimely death on September 16, 2009 left, in my judgment, an intellectual void at the NCAA. I call this an intellectual void, because Brand was the major driver of the colloquium project. It was his brain child. It was Brand who passionately believed that common ground between a large institution and university-based academics could be found. He believed that the relationship would be mutually beneficial—good research promoting NCAA reform, 
the NCAA facilitating good research by providing more data and a stage on which to report findings. He was not afraid of what he called "good research." It would uncover the problems in the system, but it would also highlight something important he believed to be true: Intercollegiate athletics at all levels provides marvelous life experiences and educational opportunities for its athletes.

Before resigning as Chair of the Forum Board in 2011, I met with NCAA President Mark A. Emmert on a couple of occasions. It was clear he shared neither Brand's academic interests nor his leadership vision. He would not take an active role in supporting the Forum. It is quite possible that plans for a post-Colloquium NCAA had begun with Emmert's arrival as the $5^{\text {th }}$ President. The die may have been cast, in other words, a couple of years before the Colloquium's official demise.

Some of the funding for the Colloquium was preserved for targeted research sponsored by the NCAA national office's research department. Faculty were invited to submit grant proposals reviewed by the NCAA research staff and an independent panel of scholars. I served for two years as Chair of the Research Panel that awarded the grants. It is also important to note that the Journal of Intercollegiate Sport remains as a Brand legacy. It is now in its $13^{\text {th }}$ year of existence and continues to provide a platform for a wide variety scholarly articles on intercollegiate sport.

\section{Final Comments and a Post Mortem}

The odd marriage between intercollegiate sport and higher education ${ }^{3}$ continues to present legal, economic, social, moral, and educational challenges. In some ways, the logic of business and that of higher education are incompatible. Bill Morgan, a fellow sport philosopher and original member of our colloquium board, called this marriage "an unholy alliance" (Morgan, 2008). This alliance pitted the interests of business - those related to sport's "front porch value," alumni and fan support, media influences, profit and sustainability, market effects on coaches' salaries, and the economic importance of defining college athletes as amateurs - all this and more against the ethos and core commitments of higher education. Scholars who study higher education and sport have called out, and will continue to call out, the tensions, contradictions, and inconsistencies in this hybrid system. Brand counted on scholarship that would balance the educationally problematic with the educationally advantageous. Some Board members did not see outcomes as balanced. Moreover, Brand was optimistic about prospects for reform. He worked for educational, economic, and social improvements within the existing framework. Some Board members believed more radical changes were needed.

The Forum also juxtaposed two cultures that embodied different ways of seeing things, of operating, of interpreting success. Brand had a foot in both cultures. Having spent much of his professional life in as an administrator in higher education, he was experienced in bridging the cultural gap between professors and institutional administrators. He allowed us to operate much as we would have on a college campus. For several years, before Brand's death, the two cultures worked reasonably well together. 
However, hopes for the Colloquium were probably unduly optimistic. Brand hoped that Faculty Athletic Representatives would be highly interested in our work. Many attended the national convention and thus would, Brand believed, be likely to attend our meetings. They did not. Most FAR's did not study sport and were not interested in athletic reform. ${ }^{4}$ For that reason alone, if not others, they chose not to attend our Colloquium sessions.

Most sport scholars prioritized attendance at meetings for specialists within their sub-disciplines. This is where they would talk to their peers and receive the most credit for tenure and annual review purposes. In addition, most institutions provided only limited travel support for faculty. For faculty not supported by large grants, decisions to attend a second or third meeting annually would be costly. Sport scholars thus attended sport sociology, sport management, exercise science, sport philosophy, child growth and development meetings, and not the NCAA Scholarly Colloquium.

It could also be the case that the colloquium presentations changed in content and tone. Many of the early papers that were critical were also constructive. In that sense they were hopeful. They pointed in the direction of reform, a priority for Brand. Some later papers, particularly those that found fault with the reform efforts, may have been less constructive in tone and content.

However, the most significant change during the six years from the initiation of the Colloquium to its demise, was the loss of Myles Brand. Nobody knows if this "grand experiment" would have continued had Brand remained President of the NCAA, but it was quite certain that its life would be short without his vision, leadership, courage, and support.

Acknowledgements: Many thanks to Dennis Cryder and Peg Brand Weiser who read an earlier draft of this paper and offered a number of editorial and substantive recommendations.

\section{Notes}

${ }^{1}$ Brand taught a course at Indiana University/Purdue University Indianapolis (IUPUI) in 2007 during his NCAA Presidency. The course (Phil 414) was titled: "Philosophy and Culture: Philosophy of Sports."

${ }^{2}$ The new data were made available in 2010 at Michigan's Inter-University Consortium for Political and Social Research. Announcement of collaboration was accessed on April 14, 2021 at the following site: https://news.umich.edu/u-m-ncaateam-up-to-distribute-student-athlete-data/

${ }^{3}$ The marriage is odd because it is virtually unprecedented around the globe. Most countries provide higher degrees of separation than does the United States between business or commercial sporting interests and the purposes and values of higher education.

${ }^{4}$ Faculty athletics representatives (FARs), with some exceptions, do not exercise strong leadership in athletic reform efforts. Most come from departments that have nothing to do with sport. All FARs are appointed by the campus President, and 
Presidents are not inclined to appoint individuals who are likely to roil the athletic waters in any way. In addition, FARs must work closely with coaches and thus, cannot afford to be seen as obstructionist . . . at least not on a regular basis. In short, a disconnect existed between Colloquium topics and FAR interests.

\section{References}

Brand, M. (2003, March 4). National Press Club Address. Delivered at The National Press Club Newsmaker Luncheon. Washington, D. C.: National Press Club. Can be accessed at www.mylesbrand.com

Brand, M. (2006). The Role and values of intercollegiate athletics in universities. Journal of the Philosophy of Sport, 33(1), 9-20. Can be accessed at www.mylesbrand.com

Brand, M. (2007, January 22). Personal correspondence from Myles Brand to Dennis Cryder.

Duderstadt, J. (2000). Intercollegiate athletics and the American university: A university president's perspective. University of Michigan Press.

Drake Group (The). (2021). Mission of The Drake Group. http://www.thedrakegroup.org

Eitzen, D. S. (1999). Fair and foul: Beyond the myths and paradoxes of sport. Roman and Littlefield.

Grasgreen, A. (2013, January 1). NCAA Ends Scholarly Experiment, Inside Higher Education. https://www.insidehighered.com/news/2013/01/17/scholars-critique-ncaa-its-annual-convention-possibly the last time

Kretchmar, S.(2008). Research, sport, and higher education: An introduction to the Journal of Intercollegiate Sport. Journal of Intercollegiate Sport, 1(1), 1-13.

Lederman, D. (2006, November 22). Association postpones planned meeting on college sports research, citing inadequate quality of papers, not their critical nature. Inside Higher Education. https://www.insidehighered.com/news/2006/11/22/ ncaa-sidelines-scholarly-conference

Morgan, W. J. (2008). Markets and intercollegiate sports: An unholy alliance? Journal of Intercollegiate Sport, 1(1), 59-65.

Powers, E. (2008). Scholars and sports. Inside Higher Education http://insidehighered.com/news/2008/01/11/ncaa

Southall, R. (2007, April 25). Lost NCAA Conference. Sports Law Blog). http://sports-law.blogspot.com/2007/04/lost-ncaa-conference.html

Shulman, J., \& Bowen, W. (2000). The game of life: Sport and educational values. Princeton University Press.

Sperber, M. (2000). Beer and circuses: How big-time college sports is crippling undergraduate education. Henry Holt \& Company.

Thelin, J. (1994). Games colleges play: Scandal and reform in intercollegiate athletics. Johns Hopkins University Press.

Zimbalist, A. (1999). Unpaid professionals: Commercialism and conflict in big-time college sports. Princeton University Press. 